\title{
The Winter's Tale by Shakespeare and the Confucian Values
}

\author{
QIAN Zhi-fu, HAN Li-li \\ Ningbo University, Ningbo, China
}

\begin{abstract}
Through comparison, this paper finds out that William Shakespeare (1564-1616), the most popular and widely respected writer in all English literatures and a great dramatist and humanist in the English Renaissance period, coincides in speaking highly of love, loyalty, intelligence, harmony, integrity, righteousness, friendship, and so on with Chinese Confucian values- the most precious treasure of Chinese traditional culture reflected in the Three Cardinal Guides and the Five Constant Virtues used by Chinese people in maintaining the stability and harmony of the whole nation and society-through vivid interpretation of human ethical relations in many of his works. At present, the world comparative literature studies have entered the third stage in the circumstance of globalization and internationalization, this finding is with paramount significance in construction of the mechanism of mutual recognition, mutual justification, mutual supplementation and mutual appreciation of heterogeneous cultures. This study, taking The Winter's Tale (1623) as a case, is about universality, unity, and shared values of the Confucianism and Shakespeare's plays in the perspective of the coexistence of multiple cultures. This paper is with four parts: (1) mechanism of mutual understanding, mutual justification, mutual supplementation, and mutual appreciation introduced in the first part; (2) the Confucian values addressed in details in the second part; (3) the third part is a case study; and (4) the last part shows how the Chinese and Western literatures and cultures can be understood, assisted, communicated, and appreciated with each other by the way of comparing the great works of Shakespeare and the Confucian values featured with universalism to a certain extent.
\end{abstract}

Keywords: "four-mutuals", the Confucian values, Three Cardinal Guides and Five Constant Virtues, The Winter's Tale

\section{Introduction}

It is YUE Dai-yun (2005) who came forward with the conception of the third stage in the developing process of the world comparative literature studies. She said:

If the first stage of the developing process of world comparative literature studies occurred mainly in France, and the second stage occurred mainly in the United States, then, in the circumstance of globalization and internationalization today, it has incontestably entered the third stage. (YUE, 2005, p. 170)

YUE (2005) insisted that, when it comes to the third stage, world comparative literature studies must be cross - cultural or interdisciplinary as well as literary studies. Scholar YUE (2005) said: "The history and the current conditions of Chinese comparative literature study has proved that Chinese comparative study is the

QIAN Zhi-fu, associate professor, Faculty of Foreign Languages and Literatures, Ningbo University.

HAN Li-li, master, Faculty of Foreign Languages and Literatures, Ningbo University. 
main reflection of comparative literature study in the third stage after France and the United States” (p. 170). Chinese comparative literature study has prospered greatly and given significant influences to the world comparative literature studies in the years after China's reform and opening up to the outside world since 1978. Scholar YUE believed that:

China's comparative literature study is neither something that came into being all by itself, or something borrowed from abroad; instead, it grows on its own soil and embodies the features of the third stage of the world's comparative literature studies. (as cited in ZOU, 2008, p. 3)

The world has been globalized and internationalized extensively with serious consequences such as the contradictions and conflicts between the peaceful co-existence and cultural imperialism, cultural hegemony and cultural fundamentalism, therefore, people in different cultural systems need to understand and communicate with each other effectively. The main role of literature is to study the human nature of people, therefore, it is extremely important to have the world comparative literature play the significant role of it in order to solve problems that human beings have met in the age of globalization and internationalization. Scholar YUE (2005) held that the functions and goals of world comparative literature studies of the third stage is "to achieve the mutual recognition, mutual justification and mutual supplementation among literatures of different cultural systems” (p. 170). According to scholar YUE, the mutual recognition refers to mutual understandings produced by interactions. It is a truth that once we understand others quite well, we can understand ourselves quite well as well. So does literature, if it is enclosed into a certain national cultural system, it would be less likely to break the original modes of thinking and accept new things. Therefore, it is important for different literatures to understand and interpret each other. Mutual justification refers to seeking common grounds and justifying different cultural elements in order to promote further and better understanding and communication. Besides, mutual supplementation refers to one kind of literature learning from other kind of literature and vice versa in order to gain strong points from others to make up their own deficiencies and pursue new progresses. This conception of "three-mutuals" is the essence of scholar YUE's theory on comparative literature study.

The authors in this paper consider mutual appreciation as an important function and goal of comparative literature study in the third stage. The authors (2008) stated that: "The history has proved that the establishment of mutual appreciation mechanism is good for the creation of human's civilization”. For example, materially, the Ancient Roman Empire and the Ancient Chinese Dynasties appreciated and admired each other, so the prosperous Silk Road was founded, and both the Chinese and Western civilization were greatly promoted; culturally, Western civilization benefited much from appreciating and admiring the excellent Chinese civilization, also the Chinese civilization especially the modern one recognizes and makes most of the creams of the Western modern civilization, so the great innovation and transformation of the Chinese modern culture is gained. The authors insist that it is not enough just to create the mechanism of mutual recognition, mutual justification, and mutual supplementation in comparative literature studies. Only when we appreciate the quint-essence of each other, can we go forward. Actually, many Chinese literati are influenced by the foreign literatures and scholars from other countries. It is worth noting that Ralph Waldo Emerson (1803-1882) and Henry David Thoreau (1817-1862), the two prominent representatives of American Transcendentalism, admired Chinese culture very much and thought that the Confucianism is consistent with their own outlooks on life. There is still another 
example, Ezra Pound, his theory on imagism is influenced by Chinese classic poems and culture deeply. ZHU (2008) said that "Ezra Pound is the disciple of the Confucianism and the admirer of Chinese classic poems. His thoughts on morality, ethical values, peace and personal relationship of the Confucianism take an active part in his literary theories and poetry creations” (p. 75).

As a matter of fact, the conception of "four-mutuals" contains the meaning of "each other" and "equality", and this is an attitude that researchers should take towards world comparative literature studies. However, whether by the way of influence study or parallel study, "researchers are always apt to attach too much importance to one side and neglect the other one" (as cited in KE \& DUSHI, 2011). It is useful and effective for researchers to study comparative literature based on the mechanism of "four-mutuals": mutual recognition, mutual justification, mutual supplementation, and mutual appreciation.

\section{The Confucian Values}

Being the most ancient, profound, and influential school of thought of China, Confucianism has undergone ups and downs or twists and turns throughout the remote and everlasting Chinese history. Confucianism "has been the most powerful influence shaping the Chinese culture and the conceptions of Chinese people for thousands of years" (as cited in Lu, Gilmour, \& Kao, 2001, p. 479), it is "not a religion but plays a religious role in Chinese culture and society; it is the beginning and center of Chinese culture and value system. To some degree, Confucianism is almost synonymous with traditional Chinese civilization” (as cited in TANG, 1995, p. 270). Confucianism refers to "a philosophy considering proper behaviors and human relationships in society” (Tamai \& Lee, 2002). It is originated as an "ethical-sociopolitical teaching” created by Confucius (551 B.C.-479 B.C.), a prominent scholar during the Spring and Autumn Period (770 B.C.-256 B.C.). Later, Confucianism became full-fledged in HAN Dynasty (202 B.C.-220 A.D.) by DONG Zhong-shu (179 B.C.-104 B.C.), a Chinese intellectual studying Confucianism. During the long feudal society period, Confucianism was a main guiding doctrine and perpetuated as the state principle for leaders to rule over the country. Besides:

The Confucianism takes the ethics and morality as its essences, attaches importance to the study of human's ethical personality, and holds that people is an ethical subject who can maintain the life of a social community and requires all human beings to engage in the improvement of moral personality so that a stable society which considers moral ideality as its principle and moral relationship as an adjustment lever. This kind of selfish departmentalism, prefer righteousness than interests and advocates 'inner lofty', has profound influence on the fashion of Chinese moral personality. (YU, 2002, p. 61)

LIANG (1989) said that the Chinese society is a society with ethics as its standards. As a guiding thought in Chinese feudal society, "Confucianism is a philosophy which deals with human relations. Its emphasis is on ethics, i.e., the moral principles a person (who is usually surrounded by various personal relations) must follow” (as cited in TANG, 1995, p. 270), the Three Cardinal Guides (Sangang 三纲) and the Five Constant Virtues (Wuchang 五常) form the cores of Confucianism. The Three Cardinal Guides include: Ruler guides the subjects, father guides the sons, and the husband guides the wife; the Five Constant Virtues refers to benevolence (ren 仁), righteousness (yi 义), propriety (li 礼), wisdom (zhi 智), and faithfulness (xin 信). The Five Constant Virtues are five ethical standards used to handle the five basic human relations between rulers and subjects, fathers and sons, husbands and wives, elders and youngers, and friends and friends. "All these 
relationships involve a set of defined roles and mutual obligations. Each individual should conform to his or her proper role and act properly to perfect the society" (as cited in a secondary source in J. WANG, G. G. WANG, Ruona, and Rojewski, 2005, p. 314). Throughout history, this whole set of Confucian values has affected Chinese history profoundly. Confucius is the first person who came forward with the conception that a king should behave like a king, a subject like a subject, a father like a father, and a son like a son (君君臣臣, 父父 子子) and use rules of benevolence, righteousness, propriety, wisdom, and faithfulness to regulate different interpersonal relationships. He contended that kings, fathers, husbands and subjects, sons, and wives should take on their own moral responsibilities, that is to say, ruler must be courteous to his subjects and the subjects must be loyal to his ruler; the parents must be kind to his children and the children must be filial to their parents. Mencius (372 B.C.-289 B.C.) further explained them as follows: there should be affection between fathers and sons, affiliation between kings and courtiers, distinction between husbands and wifes, order between seniors and juniors, and trust among friends (父子有亲, 君臣有义, 夫妇有别, 长幼有序, 朋友有信). In HAN dynasty, in order to better rule the country, to maintain the social order, and to set a standard for social ethics relations, DONG elaborated the concept more concretely and developed it into the Three Cardinal Guides and the Five Constant Virtues in his book of Annals of Fanlu (春秋繁露). The combination of the Three Cardinal Guides and the Five Constant Virtues forms a neatly integrative moral system which covers all social ethical relations. It is considered that the idea helps coordinate the interpersonal relationships of the power disparity of the feudal society and construct required communication orders, which is the precondition for good interpersonal relationship and the foundation that the feudal country realizes its long time governing.

In light of DONG Zhong-shu, the Three Cardinal Guides (Sangang 三纲) implicates that people should do things with the consideration of the whole conditions, and subordinate one's personal interests to those of the collective. The relationships between ruler and subject, father and children, husband and wife are emphasized and the roles played by the ruler, father and husband are particularly stressed. "With its emphasis on exemplary teaching and mutual responsibility", the Confucian ideology, also required that "the ruler lives up to the ideal of kinship, that the father lives up to the idea of fatherhood" (as cited in TU, 1993, p. 27). The ruler will do his best to manage the whole city, the father will set an example for his children and the husband will build a happy family with his wife. The relationship between the ruler and the subject can be interpreted as follows: The king rules the country and he needs his subjects' help to ensure the state's safety and social stability. The perfect performance is that the king takes his subjects as his brothers and gives his trusts to them, and the subjects take the king as the one they should be loyal to. The subjects have to expostulate him when the king makes a mistake, if he was so blind to their advice that leads to the country in the unstable situation and the people are unsatisfied with him, the subjects could dispose him. Therefore, the king and the subjects must be careful and have a harmonious and well cooperation. Father has the responsibility to bring up the children and cultivate them with the best qualities. For children, they have to follow his father's correct decisions, filial piety is considered to be their primary duty when they grow up. Confucius pointed out that filial piety does not mean blind obedience or compliance to parental demands. "In serving your father and mother you ought to dissuade them from doing wrong in a gentle way. If you see your advice being ignored, you should not be disobedient, but remain reverent" (Confucius, 482 B.C., p. 33). Husband is the symbolic head of the household and he holds the authority to 
represent the family, to speak and act on behalf of the family, but not against the family. Besides, the Confucian values stress that a good husband makes a good wife. Husband has no rights to command his wife that cannot command himself. If the husband is heartless, there is no need for her to follow her husband's decisions. The relationship between husband and wife is the most basic ethical relation among all human relations, and it has a direct influence on the harmony of the family and the stability of the society.

In addition, Confucianism focuses on the cultivation of virtues and maintenance of ethics to build harmonious ties between brothers, friends, and other human relations. DONG insisted that human beings should behave themselves in the guide of the Five Constant Virtues which is taken as the basic ethical rules to handle all kinds of social relationships appropriately and to maintain the social stability. Firstly, benevolence is the first and most important virtue among the Five Constant Virtues and it is essentially interpersonal and altruistic. It manifests itself in the inner mind in love and compassion for people and in avoiding harm or envy toward anyone.

Confucius outlined three relevant aspects of kindheartedness. Firstly, it "consists in loving others"; secondly, "the man of jen is one who, desiring to sustain himself, sustains others, and desiring to develop himself, develops others". Thirdly, “you should not do to others, what you do not wish upon yourself”. (Kim \& Park, 1862, pp. 231, 233)

On the other hand, Confucianism holds that benevolence has a political dimension.

Society is seen as an extension of the family. Like a father, an ideal ruler is a person who utilizes his authority for the welfare and benefit of the people and not for his own self-interests. A ruler, like a father, must be governed by virtues of both rightness and kindheartedness. If a ruler was considered totalitarian or tyrannical, he would lose the moral basis to rule and people would be justified in revolting against him. (as cited in a secondary source in Kim \& Park, 1862, p. 233)

Secondly, righteousness, means integrity, it refers to all moralities and justices with maintaining social orders as its functions. What a righteous man should be like? Mencius (293 B.C.) said: "Neither riches nor honors can corrupt him; neither poverty nor lowly condition can make him swerve from principle; neither threats nor force can bend him” (p. 40). Thirdly, it is worth noting that the concept of propriety has developed special meanings in Confucianism: It refers to the the acts of everyday life as well as decrees and regulations, and culturally, the moral expression of the order and it contains a set of principles need to be conformed. The norms of propriety can ease the contradictions between social stratum. For a ruler, if he can behave himself, he will not be indulged in sensual pleasures without limit; for common people, if he conform to the standard of propriety, he will not defy his superiors and start a rebellion; and for an individual, if he is polite, it is possible for him to be a benevolent and righteous man. Fourthly, wisdom refers to knowledge, opinion, and intelligence that helps judge right and wrong, good, and evil. "Confucian ethics does not distinguish between intellectual and moral virtues, so Confucian wisdom represents a fusion of practice and theory by an integrated heart mind” (as cited in Gier, 2001, p. 288). Finally, faithfulness is an attitude towards others and it refers to matches between deeds and words. In a word, the Five Constant Virtues of benevolence, righteousness, propriety, wisdom, and faithfulness are the basic qualities of human beings to develop a harmonious world, country, society, and family.

The Confucianism was an orthodox ideological system in feudal China, it was criticized by some people during the period of the New Culture Movement (around the May 4th Movement in 1919) and Cultural Revolution (1966-1976). A fierce criticism on Confucianism was launched, and "fight down Confucians " was a fashionable slogan. Some scholars even demonized Confucianism as a devil. After the May 4th Movement, the 
criticism on Confucius continued, during cultural revolution, the Confucianism had no prestige in society, some people thought it has no merits and lost all confidence it. But today, Chinese can treat it justly.

LONG (2005) argued that:

The Confucian values aim at building a perfect society filled with kindness and happiness. Maybe in this society, there are differences in ranks but people are tolerant and kind, they live together peacefully. Everyone has his own rights and responsibility. Politically and economically, the higher ranks are not imperious and despotic and are sympathetic with the lower ranks. (p. 377)

The Three Cardinal Guides and the Five Constant Virtues are the core of the Confucian values throughout Chinese history.

The core value of the Confucianism affirms firmly the man's value and advocates that men should do things by complying with his own nature to meet his ambition appropriately, and since the people are the foundation of the country, so in order to meet he aspirations of the people, the king should apply a policy of benevolence and morality to rule the country people. (as cited in LONG, 2005, p. 378)

Especially, as for the Five Constant Virtues:

They are what Confucians ask people to follow, whether he is king or common person... in contemporary society, these five virtues are not only still valid, but also are even more acutely needed. Similarly, I believe that the five basically reciprocal relationships (Wulun 五伦), those between ruler and minister, father and son, husband and wife, older and younger brothers, and friend and friend, are also still valid. (as cited in TU, 1996, p. 22)

Moreover, the Confucian values are suitable and widely accepted by other peoples such as Korean, Japanese, Vietnamese, and so on in the world history. It is worth noting that the thought of "humanity" takes the doctrine of loyalty and consideration for others as its principle. Therefore:

The core values of the Confucianism are featured with universalism instead of outdatedness. Humanity, harmony, sincerity and taking a mean course are gradually accepted by all men in the world, besides, they are performing the function of improving the social morality and civilizing human being in the process of globalization and modernization. (WU, 2005, pp. 66-67)

\section{Coincidence of the Confucian Values With Shakespeare's Works}

As the authors have above discussed in the paper that the main function of the comparative literature study is to realize mutual recognition, mutual justification, mutual supplementation, and mutual appreciation as well as perform the literature's glamors when it has developed into the third stage. The Confucian values, namely the Three Cardinal Guides and the Five Constant Virtues, still have positive significances on human beings today. The Three Cardinal Guides stress much on properly handling the relationships between ruler and subject, father and children and husband and wife while the Five Constant Virtues is a principle to guide human being's morals and acts. The authors found out that the Confucian values are consistent with the views of Shakespeare (1564-1616), in almost all his works. Shakespeare constructed and interpreted everything in his works on the relationships between ruler and subject, father and children, husband and wife, sisters and brothers as well as friends.

In fact, the themes of Shakespeare's many works happened to agree with Chinese Confucian values. What impressed on readers most is that in Hamlet, the Prince of Denmark (1602), a great tragedy, Hamlet's father was murdered and his throne and woman was usurped by his evil uncle Claudius. Hamlet's father is a good father and 
a good king, Hamlet is a good son and a good prince, he revenged Claudius for his father and he sacrificed himself. This famous drama totally agrees with the Confucian values, namely the Three Cardinal Guides and the Five Constant Virtues. According to the Confucian values, the king must be a good king and he effectively rules his subjects and people in his kingdom, he is not allowed to be cruel with his subjects and people. The subjects and people should obey the king's leadership when he does everything well. In Hamlet, as a subject, the vicious Claudius robs the king's power instead of obeying his rule and it leads to the unstable of Denmark and his own tragic ending. What Shakespeare wants to tell us is that only when the relationship between the king and his subjects is well coped with, is it possible to build a safe kingdom. In King Lear (1605), something wrong happened between father King Lear and his children. According to the Confucian values, the father must be good enough to his children and wise enough to judge the intentions of his children. King Lear, as a father of three daughters, is good enough but not wise enough. He is unaware of his two older daughters's deception and gives away his kingdom to the dishonest ones but nothing to the youngest daughter who is sincere to him. Finally, King Lear is discarded and ends in death on the wilderness. "Through King Lear, Shakespeare advocated that it is a nice moral and ethical responsibility to treat parents with filial respect" (as cited in WANG, 2006, p. 25), this is something coincided with the concept of filial piety of Confucian values. According to the Confucian values:

Showing filial respect for parents is the ultimate source of ethic and the general principle of morality... the thoughts on promoting filial piety, respecting the elders and loving the younger ones, from a harmonious family to harmonious society, should be inherited to improve modern people’s moral and ethical qualities. (as cited in WANG, 2006, p. 25)

In Macbeth (1605), something wrong happened between husband and wife. Macbeth was a powerful and righteous general, but stepped into the abyss of power-hunting and resulted in a tragic end after being affected and stirred up by his wife's ambitions. In The Merchant of Venice (1597), the sincerity between friends shows its great charm and the wisdom of Portia impressed us deeply. In other dramas by Shakespeare, readers can also find coincidence of the Three Cardinal Guides and the Five Constant Virtues with the basic moral principles and themes of Shakespeare's works.

\section{A Case Study: The Winter's Tale (1623) by Shakespeare}

Now the authors will take The Winter's Tale by Shakespeare as a case study to explore the features, main functions and goals of the comparative literature study at the third stage, and the Confucian values embodied in it will be analyzed detailedly.

As a masterpiece and legendary work of Shakespeare, The Winter's Tale tells us a story penetrated with benevolence, love, friendship, jealousy, and regret. It can be divided into three parts. The first part takes place in Leontes' palace in a winter of Sicilia. The king, Leontes of Sicilia enjoys his friendship and a nine month stay with his childhood friend and classmate, Polixenes, King of Bohemia and begs his longer stay in Sicilia. Polixenes refuses at first but agrees to stay when Leontes' pregnant and beautiful wife, Hermione, pleads with him. Leontes becomes possessed with jealousy, because he thinks Polixenes might have immoral relationship with Hermione. The king goes mad and forces his subject, a wise and loyal man, Camillo to poison Polixenes to death. Camillo, a man of strong sympathy and high righteousness, helps Polixenes flee away with him from Sicilia. Furious at their escape, Leontes publicly accuses his wife of infidelity, and declares that the child she is bearing must be illegitimate. His extreme jealousy and the lust of blood results in disasters. He prisons his wife. 
When the queen's loyal and brave friend Paulina brings their newly born baby-daughter to him, not only he does not soften his heart at the sight of the child, but also he grows even more angry and orders his loyal Lord Antigonus, husband of Paulina, abandon the child in a desolate place. Antigonus died and the baby daughter abandoned. The public trial of Hermione is humiliating, the Oracle read out before the court states categorically that Hermione and Polixenes are innocent. Leontes wastes lot of precious time against Hermione and his son Mamillius died too. Hermione, meanwhile, falls in a swoon, and is carried away by Paulina, who subsequently reports the queen's death to her heartbroken and repentant husband. When Leontes hears these news, he regrets at last, and vows to spend the rest of days atoning for the loss of his son and his queen.

Antigonus names the baby Perdita and puts her in the cradle at the seashore before his death, and a kindly old shepherd takes Perdita home and brings her up with his son for the next 16 years.

Then the story enters into the second part. Sixteen years pass. Camillo, now a subject of Polixenes, misses his homeland very much and begs the Bohemian king allow him to return to Sicilia. Polixenes depends on him so much that he refuses to let him leave his land. Later the Bohemian king finds out that his son, Prince Florizel, has fallen in love with a shepherd girl, Perdita. They disguise and follow Florizel to the shepherd place and Polixenes becomes furious when he finds out that his son is wooing Perdita. He threatens the Old Shepherd and Perdita, and orders his son never see the shepherd's daughter again. With the wise aid of Camillo, however, who longs to see his native land and his old king again, Florizel and Perdita take ship for Sicilia, using the clothes of Autolycus as a disguise. They joined together on their voyage with help of the Old Shepherd and his son following Autolycus' instruction.

Finally, it comes up to the third part of the story. After all kinds of frustrations, Perdita turned out to be the daughter of Leontes and they are permitted by their fathers to love each other. The friendship between Leontes and Polixenes is recovered. At last, Leontes, Polixenes, Camillo, Florizel, and Perdita go to Paulina's house in the country and pay a salutation to a recently finished statue of Hermione. The sight of his wife's statue makes Leontes distraught, but to everyone's amazement, the statue comes to life-it is Hermione who restores to life. As the play ends, Paulina and Camillo are engaged and celebrated .

The three acts of the first part are full of intense psychological conflicts and contradictions among the major characters. Things take place between the king Leontes and his subjects, husband and his wife are depicted vividly. The jealous and strong-headed king Leontes doubts that his wife has immoral relationship with his best friend Polixenes, he forces his subjects to obey his irrational and cruel orders. He accuses his subjects badly instead of taking their advices. He orders Camillo like this: “To bide upon't: thou art not honest; or, If thou inclin'st that way, thou art a coward/Which hoxes honesty behind, restraining From course requir'd" (Shakespeare, 1997, p. 318); then accuses him further: "It is; you lie, you lie/I say thou liest, Camillo, and I hate thee/Pronounce thee a gross lout, a mindless slave/Or else a hovering temporizer that Canst with thine eyes at once see good and evil/Inclining to them both” (Shakespeare, 1997, p. 318). Camillo is benevolent and wise enough, he knows that he cannot change the ferocious king, so he decides to flee with Polixenes. After Camillo, the king threatens his another subject Antigonus to discard his conscience and abandon the little baby. According to the Confucian values, it is the ruler who guides the subject. But when the ruler is dictatorial and cannot distinguish wrong from right, it must lead to the worsening of the relationship between the ruler and his subjects, or when the king lacks of the necessary qualities to rule his country, such as benevolence, the loyal subjects would flee to other countries. This is very true in The Winter's Tale. According to the Confucian values, it is the 
husband who guides the wife. If the family lives in harmony, all business and family affairs will prosper. The husband is in the guiding position, he plays a very important role in handing the family ethical relations, but once he does something wrong and cannot distinguish right from wrong and treats his wife bad, it will surely damage the family and cause troubles. If the king himself has a bad relation with his wife, then he sets a bad example for his people, and it will lead to the instability of the whole country. As a husband, the king Leontes groundlessly doubts his innocent wife and puts her on a public trial. The noble queen has her dignity, she stands and says firmly when questioned by his husband:

To say "Not guilty". Mine integrity Being counted falsehood shall, as I express it, Be so receiv'd/But thus-if pow'rs divine Behold our human actions, as they do, I doubt not then but innocence shall make False accusation blush, and tyranny Tremble at patience-As I weigh grief, which I would spare; for honor/“Tis a derivative from me to mine/And only that I stand for/I appeal To your own conscience, sir... Have strain'd t" appear thus; if one jot beyond,/The bound of honor, or in act or will, That way inclining, hard'ned be the hearts/Of all that hear me, and my near'st of kin/Cry fie upon my grave! (Shakespeare, 1997, p. 326)

From above examples, we could find that Shakespeare agrees with the Confucian values, i.e., the Three Cardinal Guides and the Five Constant Virtues.

According to the Confucian values, the nature of human-being is virtue. The nature of Leontes is virtue too. Then in the second part, Leontes regrets and suffers for almost 16 years for his ever-made mistakes. Just like a Chinese old saying that non-saints, cannot too, rectifies the hell, Leontes is surly a non-saint. But he is lucky, because he spends 16 years correcting his mistakes. His wife and children as well as his subjects forgive him, at last, they live together happily. This is what benevolence advocated by the Chinese Confucian values makes the difference. The king's sincerity, Camillo's righteousness and wisdom, and Florizel's fidelity are depicted vividly in The Winter's Tale. The king of Bohemia treats his subject Camillo as a close friend, and he always takes his good advice, that is why Camillo helps him for 16 years. The king of Sicilia corrects his own mistakes, that is why Camillo returns to his kingdom. The prince Florizel is noble in his heart, that is why he is willing to marry the girl he loves regardless of her status. He runs away with his love even when his father is against them strongly and the ethical relationship between father and son ends. Shakespeare always lauds some merits coincided with the Confucian values, i.e., the Three Cardinal Guides and the Five Constant Virtues and blame demerits violating those values in his dramas.

Shakespeare looks through into the human nature insightfully and uniquely. Leontes creates happiness and well-being for his family, his subjects and his people when he does everything well but his wrong-doing creates disasters not only for his innocent wife and the 7-year old boy Mamillius and baby-daughter Perdita, but also for his subjects and his people even to himself. Leontes is a good king but an ordinary man. He makes and corrects mistakes. Camilo is wise and benevolent and he follows good orders given by his kings but refuses to follow them when he finds out they are wrong. That is why he has a happy ending at last. Antigonus can only follow the orders given by his king whether they are good or not, that is why does not have a good ending at last. Paulina is kind, brave, and wise. She tries her best to correct Leontes' fault and help Hermione when she is imprisoned and on the trial. Paulina hides Hermione at a secret place in the countryside, and saves the royal family's happiness finally. That is why she could enjoy a happy life with Camilo in her rest life. Siemon James Edward thought that The Winter's Tale probes into the two aspects of human nature, one is goodness, the other is evilness. In fact, whether 
evil or kind, neither can define one's life by depending on the only one side. This is consistent with the Confucianism. Confucius thought that man's nature is good at birth, even if he does many evil things, he also should be forgiven and corrected by education, goodness and evilness cannot be separated. Therefore, from a perspective of modern view, the Confucianism and the mindset of Shakespeare can have an exchange and a dialogue to promote each other's development.

\section{Conclusions}

Scholar TANG Yi-jie pointed that: "There existed some elements with 'universal values' in all kinds of national cultures. It is the only road to find the 'universal value' in different cultures by way of communications and dialogues between them” (as cited in CHEN, 2012, p. 190), and the elements in different cultures and literatures with universal values can promote human beings' advancement in all around way, so it is emergent to build the system of "four-mutuals" between different literatures and cultures studies. At The 17th Conference of ICLA (International Comparative Literature Association) held in Hong Kong on August 8-15, 2004, scholar YUE (2005) declared with a firm belief that:

China's comparative literature study deeply rooted in China's traditional culture surely plays a unique and significant role in appeasing the intense conflicts of ideologies and ameliorating the condition of fragment, detachedness and isolation brought by post-modernism and it gains a revival and bright future in an era of globalization. (p. 1)

The Chinese and Western cultures and literatures stand for the great achievements of human being's civilization, higher requirements are for world comparative literature studies. The Chinese Confucian values are the symbols of the Chinese culture throughout the history for almost 5,000 years and set a whole set of moral standards for people to handle with all kinds of ethical relations. It has positive impact on maintaining the normal operation of a country and promoting the harmonious social ethical relations. Shakespeare, a distinguished dramatist, created a huge fortune in human's literature. From what the authors have discussed, the Chinese Confucian values have shared items with Shakespeare's thoughts. In a certain sense, these two are featured with universalism and can enlighten us a lot in studying comparative literature. The mechanism of mutual understanding, mutual justification, and mutual supplementation, especially, the mechanism of mutual appreciation between literatures, have great influence on cultural exchange and communication. The Eastern and Western cultures should seek common grounds and put aside differences, they should understand, justify, supply, and appreciate each other to gain each other's strong points, and it will surely promote the common development of the world's cultures and literatures.

\section{References}

CHEN, F. (2012). The value orientation of the Confucianism and the cultural development of society. Jinan: Dongyue Tribune. Confucius. (482 B.C.). The analects (p. 33). Beijing: China Classics Publishing House.

Gier, N. F. (2001). The dancing RU: A Confucian aesthetics of virtue (p. 288). Hawaii: University of Hawaii Press.

KE, L., \& DUSHI, Q. F. (2011). TV play The Journey to the West in Vietnam. Journal of School Chinese Language and Culture Nanjing Normal University, 6, 170.

Kim, U., \& Park, Y.-S. (1862). Confucianism and family values (pp. 231, 233). German: VS Verlag Sozialwissenschaften.

LIANG, S. M. (1989). The essences of Chinese culture (Zhongguo Wenhua Yaoyi). Hong Kong: Joint Publishing Corporation.

LONG, S. Y. (2005). On the core value and advanced-culture quality of Confucianism. Journal of Hubei University (Philosophy and Social Science), 32(4), 68. 
Lu, L., Gilmour, R., \& Kao, S. F. (2001). Cultural values and happiness: An east-west dialogue. Journal of Social Psychology, 141(8), 479.

Mencius. (293 B.C.). The collected works of Mencius (p. 40). Beijing: China Classics Publishing House.

QIAN, Z. F. (2008). The foundation of the system of mutual appreciation-An important part of comparative literature in the third stage. Journal of Literature and Arts, 131, 2.

Shakespeare, W. (1997). The complete works of William Shakespeare (pp. 318, 319, 326). New York: Random House Value Publishing.

SHEN, F. (2002). Dionysiac myth in The Winter's Tale. Journal of Beijing University of Aeronautics and Astronautics (Social Sciences Edition), 12.

Tamai, K., \& Lee, J. (2002). Confucianism as cultural constraint: A comparison of Confucian values of Japanese and Korean university students. International Education Journal, 3(5), 33-49.

TANG, Z. L. (1995). Confucianism, Chinese culture, and reproductive behavior. Population and Environment: A Journal of Interdisciplinary Studies, 16(3), 270.

TU, W. M. (1993). Way, learning, and politics: Essays on the Confucian intellectual. Albany, N.Y.: State University of New York Press.

TU, W. M. (1996). Confucian traditions in east Asian modernity: Moral education and economic culture in Japan and the Four Mini-Dragons. Cambridge: Harvard University Press.

WANG, J., WANG, G. G., Ruona, W. E. A., \& Rojewski, J. W. (2005). Confucian values and the implications for international $H R D$. London: Human Resource Development International.

WANG, Z. X. (2006). Constructing an ethical Utopia: The aesthetic significance of Shakespeare's play. Beijing: Foreign Literature Studies.

WU, G. (2005). The orientation of the contemporary Confucianism (pp. 66-67). Shanghai: The Great Dictionary of Chinese Language Press.

YU, M. S. (2002). Conflicts and fuses: Between Confucians ideas and western ideas on values. Journal of Qinghai Normal University (Philosophy and Social Sciences), 4.

YUE, D. Y. (2005). The third stage of comparative literature development. Journal of Social Sciences, 9, 170.

ZHU, W. (2008). The mutual influence of Chinese and American poetics. Chengdu: Sichuan People’s Publishing House.

ZOU, J. J. (2008). Text, literature and culture: Impetus for comparative literature in China. Beijing: Foreign Literature Studies. 